\title{
ПОНЯТИЕ НРАВСТВЕННОСТИ. НРАВСТВЕННОЕ ВОСПИТАНИЕ
}

\author{
А.С. Третьякова \\ Московский гуманитарный университет
}

\begin{abstract}
Аннотация: В статье показано, что нравственность формируется в специально организованном прочессе, составными частями которого являются нравственное просвещеене, выработка этических убеждений, совершенствование нравственных чувств, формирование нравственного поведения, этических оченок, отношений, мировоззрения. ребенок

Ключевые слова: нравственность, нравственное воспитание, поведение, мораль, поступок,
\end{abstract}

\section{THE CONCEPT OF MORALITY. MORAL EDUCATION}

\author{
A.S. Tretyakova \\ Moscow University for the Humanities
}

\begin{abstract}
The article shows that morality is formed in a specially organized process, the components of which are moral education, the development of ethical beliefs, the improvement of moral feelings, the formation of moral behavior, ethical assessments, attitudes, and worldview.
\end{abstract}

Keywords: morality, moral education, behavior, morality, act, child

Нравственность, мораль возникли на заре формирования общества. Определяющая роль в этом принадлежит труду. Человек не смог бы противостоять силам природы без взаимной помощи, без обязанностей перед своим родом. Нравственность регулирует человеческие взаимоотношения. Она существует в религиозных заповедях, мудрых притчах, народных пословицах, указывающих, как следует поступать, а как - нет. Соблюдая нормы нравственности, человек содействует общественной жизнедеятельности. При этом общество, пропагандируя и развивая конкретную мораль, воспитывает личность, соответствующую своему эталону. Таким образом, нравственность поддерживается силой коллективного мнения, либо соблюдается убеждениями.

Каждое время оставило свои толкования нравственности. Еще Аристотель утверждал: «...нравственно прекрасным зовут справедливого, мужественного, благоразумного и вообще обладающего всеми добродетелями человека» (Аристотель, 2008: 60).

В понимании В.И. Даля «учение о нравственности, - правила для человеческой совести и воли» (Даль, 2005: 345). Нравственное существование более важно, нежели вещественное.

По А.Н. Леонтьеву «нравственность это внутренние, духовные качества, которыми руководствуется человек, этические нормы, правила поведения, определяемые этими качествами» (Леонтьев, 2008: 414).

О наличии нравственного начала в человеке можно судить в случае, если 
эта нравственность является душевной потребностью, когда она контролируется личными принципами и воззрениями, которые и есть основа нравственного воспитания. Важнейшими критериями нравственности могут быть взгляды человека, этические принципы, ценностные ориентации, поступки в отношении окружающих людей. Поступок - это «действие или состояние человека, но оно становится поступком только во взаимосвязи с пробуждающими его целями, мотивами и намерениями» (Столярова, 2010: 25). Под поведением понимают «совокупность человеческих поступков. Выделяются внешние проявления и внутренняя мотивация поступков» (ФГОС НОО, 2009: 5).

Нравственная устремленность человека обнаруживается не в отдельных поступках, а в их совокупности, которая оценивается, преимущественно, через умение человека энергично выражать жизненную позицию. Нравственная ценность личности состоит в ее готовности утверждать моральные принципы общества в предпочтенной сфере деятельности.

Отсюда следует, что нравственным может считаться человек, для которого нормы морали являются привычными формами поведения. Привычное поведение вырабатывается при условии многократного повторения. Оно даёт возможность человеку в равных, похожих условиях поступать всегда так, как необходимо.

По мнению М.И. Рожкова, несокрушимое ядро «нравственного убеждения формируется в ранние периоды детства и отрочества. В это время нравственные ценности становятся доступными для понимания только в ситуации четкой наглядности, очевидности морального смысла того, что он видит, делает, наблюдает» (Рожков, 2017: 170).

Отечественные просветители А.Н. Радищев, В.Г. Белинский, А.И. Герцен также обращали внимание на воспитание нравственных качеств у детей, считая его непременным условием для гармоничного развития личности. К.Д. Ушинский считал, что нравственность не зависит от уровня умственного развития.

В основе нравственного воспитания находятся нравственные чувства. Б.Т. Лихачев определяет нравственное чувство, как устойчивое эмоциональное чувство, переживание действительных нравственных отношений и взаимодействий. Нравственные нормы реорганизуются в индивидуальную нравственность только посредством чувственного постижения их ребенком. Одновременно школа должна добиваться того, чтобы младшие школьники глубоко постигли нравственные поведенческие нормы, восприняли их и следовали им в обыденной жизни. Поведение ученика соответственно моральным нормам свидетельствует о наличии у него выработанных нравственных убеждений. Понятия нравственности становятся убеждениями тогда, когда они подкреплены чувствами и волей. Со временем взгляды становятся глубже, устойчивее, глубоко укореняются в детской личности. Чем богаче жизненный опыт детей, тем глубже, полнее глубина усвоения ими нравственных понятий, они напрямую зависят 
от насыщенности, богатства жизненного опыта. Вырабатываются нравственное сознание, представления и оценки. Детское поведение, основанное на устоявшихся нравственных понятиях, принципах всегда сопряжено с ощущением радости, удовлетворения.

Таким образом, мы видим, что в педагогике имеются разнообразные подходы к решению проблем воспитания нравственных качеств. Их можно использовать учителю при формировании нравственных качеств детей младшего школьного возраста, которое происходит на протяжении всего обучения в начальной школе. В процессе работы раскрывается и совершенствуется детская личность, учитель с детьми взаимодействует более полно. Поэтому учитель способен выбирать наиболее действенные средства и методы для организации воспитания нравственности у младших школьников.

Современная наука утверждает, что в разные периоды возраста возможности для нравственного воспитания неодинаковы. Установлено, что младший школьный возраст наиболее восприимчив к овладению нравственными правилами и нормами. Основой воспитания, обусловливающей нравственное развитие в младшем школьном возрасте, является становление гуманистических взглядов детей с опорой на чувства, эмоциональную чуткость (Агалакова, 2015: 41).

Воспитывая нравственные качества младших школьников, нужно принимать во внимание особенности их возраста и психики:

1) Стремление к игре. В ходе игровой деятельности ребенок постигает нормативное поведение. В играх от ребенка требуется умение придерживаться определённых правил, нарушения которых дети особенно остро замечают и прямо выказывают свое осуждение нарушившему правила. Ребенок, не подчинившийся общему мнению, может даже покинуть игру. Так, осваивая нормы поведения в коллективе, они учатся говорить правду, быть честными, справедливыми. Игра учит действовать по правилам от тех, кто в ней участвует.

2) Дети не могут продолжительное время выполнять монотонную работу. Они теряют внимательность, поэтому виды деятельности лучше менять в ходе занятий.

3) Младшие школьники не имеют ещё отчётливых представлений о нравственности, что связано с недостатком опыта.

4) Может возникнуть противоречие между знанием, как нужно, и использованием на деле.

Особенное место в нравственном воспитании отводится формированию дружелюбия, доброжелательности, справедливости, честности, отзывчивости, гуманности, милосердия, вежливости. Рассмотрим эти качества подробнее.

Сочувствие - свойство, которое побуждает человека к бескорыстию, по причине имеющейся заботы о благополучии других людей. Благодаря сочувствию мы осознаем ценность других людей. 
Используя эмпатию, можно создать непроизвольную нравственную мотивацию, поощряя детей за любой совершенный ими нравственный поступок. Замечая радость другого человека, дети при этом испытают удовлетворение. Позже выработается потребность помогать людям.

Вежливость красит человека, способствует его привлекательности. Она является одним из признаков воспитанности и основана на уважении. Без нее нельзя вообразить человеческие взаимоотношения.

Отзывчивость - непременное уважение к просьбе, помощь в любой ситуации. Это может быть дело, поступок, слово.

Гуманность - любовь, чуткость к человеку, почтение к личности; доброта ко всему живому; человечность, человеколюбие. Это определённые установки личности относительно человека, группы людей, живых существ, определённые нравственными нормами и ценностями.

Дружелюбие - позитивная нравственная черта, которая выражает неподдельное отношение к людям, целомудренные чувства, склонность к спокойному доброму сосуществованию, к мирному решению завязывающихся конфликтов. Дружелюбие как индивидуальное качество является основой воспитания детей в мире, в любви, формирования у них влечения к спокойному и выдержанному образу жизни.

Доброжелательность выражает благорасположение, расположение людей друг к другу, желание добра, блага, успеха; это умение выражать радость успехам, счастью, радости других; это способность прощать ошибки, быть терпимым к недостаткам.

Справедливость характеризует человека, придерживающегося принципа соответствия морали и закона. Справедливость заключает в себе представление о соответствующем порядке человеческих отношений. Чувство справедливости в детском сознании обострено. Это критерий, по которому оцениваются все происходящие события.

Честность - способность сдержать данное обещание, правдолюбие, искренность.

В арсенале учителя множество средств и методов, применяемых при воспитании качеств, которые относятся к нравственным. Всеметоды используются в соответствии с целями воспитания, но ограничены возможностями детского возраста.

Известно несколько видов, по которым группируются методы нравственного воспитания. Г.И. Щукина (Щукина, 33), методика которой наиболее популярна, разделяет их на группы:

1. Рассказ, лекция, объяснение, беседа на тему этики, пример, обсуждение, которые способствуют становлению сознания.

2. Упражнения, воспитательные ситуации, которые помогут организовать работу и создать опыт. 
3. Соревнование, порицание, похвала: действуют как стимулы.

У всех своя специфика и область применения. На первый взгляд несложно, но требует мастерства.

Убеждение призвано изменить поступки и поведение: нравственные ориентации, верная оценка поступков, поведение среди людей.

Рассказ на моральную тему живописно, ярко подает события и факты. Касаясь чувств, вызывает понимание и усвоение значения этических оценок и норм. Выполняет функции: когнитивную, обогащение опыта детей, позитивный пример.

Для того чтобы рассказ являлся эффективным, он должен отвечать общественному опыту детей, в этом возрасте он небольшой, имеет эмоциональную окраску, доступен.

Иллюстрации, верно подобранная музыка способствуют более острому восприятию рассказа. Значима и окружающая обстановка, которая вызывает эмоции.

Рассказ обязательно должен быть прочувствован детьми. Впечатление от услышанного должны остаться в детской памяти надолго (Каменская, 2008).

Этическая беседа влияет на разум и поведение детей. Посредством данного метода вырабатываются и совершенствуются знания о нравственности. На их основе формируется внимание к проблемам, связанным с нравственностью и вырабатывается склонность к оценке, а также усвоению понятий и представлений, связанных с этикой. Этическая беседа преследует цель углубления, укрепления этических понятий, обобщения и фиксации знаний, становление системы нравственных воззрений и позиций.

Структура беседы для начальной школы несложная. Лучше всего использовать такой порядок: анализ фактов, их оценивание, обобщение и вывод, сделанный самостоятельно (Каменская, 2008).

Метод примера влияет на младших школьников с эмоциональной стороны, благодаря чему нравственные нормы легче усваиваются. Детям рассказывают о знаменитых людях. Показательны примеры из литературы, кино, либо мультфильмов. Мультипликационные примеры отличаются наглядностью, что актуально для данного возраста.

Метод поощрения показывает позитивные оценки поведения, навыков и привычек младших школьников. Данный метод нужно применять осторожно и соблюдать определённые правила и условия:

1) поощрять нужно за хорошие поступки и поведение, не путая их с желанием получить поощрение;

2) нужно следить, чтобы полученное поощрение не вредило другим детям;

3) непременная справедливость и своевременность поощрения;

4) нужно принимать во внимание личные качества каждого ребенка. 
Метод наказания применяется как педагогическое воздействие, указывающее школьнику на поступки, совершать которые нежелательно, с целью их пресечения. Метод может использоваться в разных видах: дополнительные обязанности; ограничения в чем-либо; осуждение, порицание.

Нужно соблюдать определённые правила и условия:

1) справедливость наказания, оно не должно унижать;

2) наказывая ученика, нужно быть уверенным в его виновности;

3) ученик должен понимать причину наказания;

4) наказывая, нужно искать и подчёркивать позитивное в поведении ученика;

5) наказывая, нельзя лишать поощрения.

Таким образом, мы видим, что в педагогике имеются разнообразные подходы к решению проблем воспитания нравственных качеств. Их можно использовать учителю при формировании нравственных качеств детей младшего школьного возраста, которое происходит в продолжение всего хода обучения в начальной школе. В процессе работы раскрывается и совершенствуется детская личность, учитель с детьми взаимодействует более полно. Поэтому учитель способен выбирать наиболее действенные средства и методы для организации воспитания нравственности у младших школьников.

\section{СПИСОК ЛИТЕРАТУРЫ}

Агалакова Е.В. (2015)Духовно-нравственное воспитание младших школьников: результаты эмпирического исследования // Вестник ВятГУ. № 1-3. С. 32-36.

Аристотель (2004) Сочинения в 4-х томах. Т. 4.

Даль В.И. (2005) Толковый словарь живого великорусского языка. М., т.11.

Каменская В.Г. (2016) Детская психология с элементами психофизиологии: учеб. пособие / В.Г. Каменская. - М.: ФОРУМ: ИНФРА-М, 2016. - 288 с.

Леонтьев А.Н. (2008) Деятельность, сознание, личность. М.

Рожков М.И. (2015) Организация воспитательного процесса в школе: Учебное пособие для студ. высш. учеб. заведений / М.И. Рожков, Л.В. Байбородова. - М.: ВЛАДОС. 256 с.

Столярова Е.В. (2010) Проект духовно-нравственного воспитания и образования «Возрождение» // Муниципальное образование: инновации и эксперимент. № 5.

Щукина Г.И. (2000) Учеб. пособие. - М.: Просвещение.

Федеральный государственный образовательный стандарт начального общего образования (утвержден приказом Минобрнауки России от 6 октября 2009 г. No 373, с изменениями (утверждены приказом Минобрнауки России от 26 ноября 2010 г. No 1241) [Электронный pecypc] URL: https://normativ.kontur.ru/document?mo duleId=1\&documentId=194110 (дата обращения: 20.12.2020). 
Tретьякова Анастасия Серzеевна - магистр 3 курса кафедры педагогики и психологии высшей школы Московского гуманитарного университета. Научный руководитель: доцент кафедры педагогики и психологии высшей школы А.А. Фортунатов. Адрес: 111395, Россия, г. Москва, ул. Юности, д. 5. Тел.: +7 (499) 374-74-95. Эл. Адрес: anmoshkina@yandex.ru

Tretyakova Anastasia Sergeevna, Magister, 3rd year, Department of pedagogy and psychology of higher school. Scientific supervisor: Associate Professor of the Department of Pedagogy and Psychology of Higher School A. A. Fortunatov. Address: 111395, Russia, Moscow, st. Yunost, 5 tel.: +7 (499) 374-74-95. Email: anmoshkina@yandex.ru 